\title{
Population Briefs, Vol. 11, no. 3
}

Population Council

Follow this and additional works at: https://knowledgecommons.popcouncil.org/ series_newsletters_popbriefs How does access to this work benefit you? Let us know!

\section{Recommended Citation}

Population Briefs 11(3): New York: Population Council, 2005. 


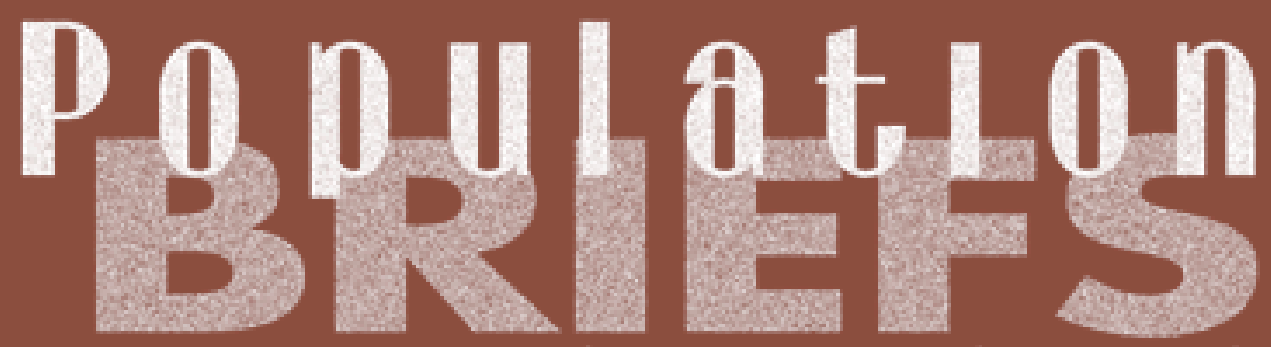

Reports on Population Council Research

\section{Physical Abuse Common During Pregnancy in South Asia, Studies Find}

Population Council researchers recently completed studies in Pakistan and Nepal of attitudes and behaviors surrounding violence against women during pregnancy. These investigations were some of the first of their kind in South Asia. They probed the level of awareness of domestic violence among obstetrician/gynecologists (OB/GYNs) in Karachi, Pakistan, and of $\mathrm{OB} / \mathrm{GYNs}$, assistant nurse midwives, and traditional birth attendants in Kathmandu, Nepal. Postpartum women in Karachi and

Kathmandu were surveyed to augment knowledge about the scope, context, and consequences of violence faced by pregnant women. In a separate study, men in Karachi were interviewed about domestic violence. Although preliminary and limited to two urban areas, the studies suggest a high level of physical abuse during pregnancy and provide some empirical basis for developing realistic interventions to protect the lives of women and their children.

In addition to infringing on women's human rights, domestic violence poses significant risks to women's health, including their reproductive health. During the stress of pregnancy, domestic violence may begin or intensify, harming the mother as well as the fetus. Violence during pregnancy has been associated with maternal death; pregnancy complications, including placental abruption, premature rupture of membranes, and preterm birth; and adverse outcomes, including abortion, miscarriage, and low birthweight.

Obstetrician Fariyal F. Fikree spearheaded the studies in Pakistan and Nepal. Fikree, now at the Population Reference Bureau, was Population Council director of regional health programs in Cairo, Egypt. In each country, researchers interviewed $100 \mathrm{OB} / \mathrm{GYNs}$ to assess their awareness regarding the magnitude of violence against women, violence during preg-

\section{"Obstetricians were}

shocked that the level of physical abuse during pregnancy was as high

as women reported."

nancy, and the effects of violence on maternal and fetal health. The study also explored providers' opinions on potential interventions and barriers to these programs. In both cities, the vast majority of $\mathrm{OB} / \mathrm{GYNs}$ are women.

To supplement the information collected from these providers, researchers also interviewed 300 women in each city who had recently given birth in a large public maternity hospital. Investigators assessed their awareness of and attitudes toward violence against women (particularly violence during pregnancy), their care-seeking behavior for injuries associated with domestic violence, and their attitudes toward the responses of physicians or health care workers. In Kathmandu, where home deliveries are common, investigators also interviewed 50 women who delivered their babies at home, 50 assistant nurse midwives, and ten traditional birth attendants.

\section{Obstetricians' awareness}

Obstetricians in both locations and other birth attendants in Kathmandu were nearly universally aware of severe pregnancy complications caused by physical abuse. The majority of obstetricians interviewed believed that more than 30 percent of women in Pakistan and Nepal are the victims of domestic violence. But the majority of $\mathrm{OB} / \mathrm{GYNs}$ thought that the prevalence of domestic abuse in their own practices was less than 10 percent. Types of physical abuse mentioned by doctors included beating, slapping, kicking, and pulling hair. Injuries mentioned included bruises, cuts, burns, and vaginal trauma.

In both locations, about three-quarters of obstetricians agreed that a health care provider's role includes helping domestic violence victims. In Kathmandu, 77 percent of obstetricians approved of routinely screening patients for signs of abuse, and 29 percent said they regularly screened their antenatal patients. In Karachi, 47 percent of obstetricians were favorably inclined to routinely screen patients, though only 3 percent reported routine screening for domestic violence at antenatal visits (see table). The main reasons given for not routine-

continued on page 6 


\section{Low Chemical Exposure May Speed Male Puberty}

A recent, much-publicized study highlighted the adverse effects that prenatal exposure to chemicals known as phthalates has on the genital development of male infants. Population Council biomedical researchers are now studying the effect of prepubertal exposure to these chemicals on the onset of male puberty. They have found that exposure to low levels of the chemicals can alter levels of a number of sex hormones, increase the proliferation of cells in the testes, and significantly accelerate the onset of puberty. Phthalates are chemicals used to make plastics — such as those used in food packaging and infant toys - more flexible. They are also used as stabilizers in many common cosmetic products, such as nail polish, shampoo, and lotion.

Because they are used so widely, exposure to these chemicals is difficult to avoid. In fact, a recent study by the U.S. Centers for Disease Control and Prevention (CDC) found low but relatively widespread exposure to phthalates among the U.S. population. Levels of 11 of the 12 phthalates for which the CDC tested were higher in children than adults.

\section{The most abundant phthalate}

Population Council reproductive biologist Matthew P. Hardy and his colleagues are studying the most abundant phthalate in the environment, DEHP [di-(2-ethylhexyl) phthalate]. The U.S. Department of Health and Human Services has estimated that the average person in the United States takes in $5.8 \mathrm{mg}$ of DEHP every day.

Many studies of these and other chemicals have been criticized because the studies use very high chemical exposures, much higher than people would likely experience in the normal course of their lives. (Industrial accidents can result in very high exposures to chemicals, but these are rare.) Hardy and his colleagues have made a point of using low, chronic chemical exposures in their experiments. Humans encounter DEHP primarily through residues in foods. "We gave rats DEHP

orally in corn oil at levels proportional to those to which humans might be exposed," explains biomedical scientist Benson T. Akingbemi of Auburn University. Akingbemi was previously a postdoctoral researcher in Hardy's laboratory.

For four weeks or longer, Hardy and his team exposed male prepubertal rats to DEHP. They found that prolonged exposure to DEHP induced high levels of luteinizing hormone (LH), which primarily regulates testosterone levels. Similarly, the researchers found that blood levels of the sex hormones estradiol and

"These findings fit

with the idea that

DEHP is an anti-

androgen."

testosterone increased by more than 50 percent in exposed rats.

Paradoxically, however, testosterone output by individual Leydig cells, which produce the hormone, actually decreased. The rise in blood hormone levels came about because the total number of these hormone-producing cells increased. The number of Leydig cells in rats exposed to DEHP was 40 to 60 percent higher than in control rats. While none of the DEHP rats developed cancer, proliferation of Leydig cells has been implicated in some testicular cancers.

\section{Onset of puberty}

Next, Hardy and his colleagues looked at the effect of DEHP on the onset of puberty in young male rats. They examined the foreskin on the rats' penises to determine the onset of puberty. Until puberty, the rat foreskin is attached to the penis; at the onset of puberty, the foreskin separates from the penis.
During each of the 28 days of the study, the researchers gave rats either a low oral dose of DEHP in vegetable oil, a high oral dose of the chemical in vegetable oil, or vegetable oil alone. They measured blood testosterone levels in the rats on day 14 and day 28 of the experiment. Although testosterone levels in control rats and in those receiving a low dose of DEHP were the same at day 14, testosterone levels were significantly higher in the low-dose rats at day 28. In contrast, testosterone levels were significantly lower in high-dose rats than in control rats by day 14 . By day 28 , testosterone levels in high-dose rats had returned to control levels. Moreover, puberty started significantly earlier in rats receiving a low dose of DEHP than in high-dose or control rats.

"We think all of these findings fit with the idea that DEHP is an anti-androgen. We propose that DEHP inhibits the production of testosterone by Leydig cells. The lowered testosterone levels signal the brain to release luteinizing hormone," explained Hardy. "We think that a chronic over-stimulation with $\mathrm{LH}$ may cause the proliferation in Leydig cells that we observed. Though individual Leydig cells are producing less testosterone, there are significantly more cells, so the blood testosterone level increases. Thus, our findings indicate that low levels of DEHP may shift the body's hormonal equilibrium to a higher level as the endocrine system struggles to overcome the anti-androgenic propensities of the chemical. The overall increase in circulating testosterone is sufficient to significantly speed the onset of puberty in male rats." 


\section{Expanding a Successful Health Care Initiative}

What is the best way to help institutions replace poorly functioning policies and programs with ones that have been shown to work well? "In Ghana, we are taking mechanisms that work for individual behavior change and adapting them for the purpose of policy and program change within institutions," says Population Council demographer James F. Phillips. Phillips and his Council colleagues are collaborating with the Ghana Health Service to help that organization overcome the gap between research and action.

\section{Community-based Health Planning and Services}

The Ghana Community-based Health Planning and Services (CHPS) initiative aims to scale up an innovative approach to delivering primary health care services on a national level. CHPS is implemented in six stages. Currently, 90 of 110 districts are at the first, or planning, stage. Twenty districts have completed all six stages of implementation in one or more district zones. Ministry of Health teams from Burkina Faso, Ethiopia, and Sierra Leone have come to Ghana to observe CHPS in action, as they begin to implement similar nation-wide programs.

CHPS is based on findings from an experimental study conducted by the Navrongo Health Research Center, a Ministry of Health field station in rural northern Ghana. The Navrongo model uses volunteers from the community and paid Community Health Officers (CHOs). The volunteers focus on promoting family planning and reproductive health among men. The $\mathrm{CHOs}$ are specially trained nurses who live and work in communty-constructed health centers and provide health and family planning services door to door, traveling by motorcycle.

Health care in Ghana generally has been available from fixed-location clinics. But studies have shown that more than 70 percent of all Ghanaians live more than five miles (eight kilometers) from the nearest health care provider.
Contemplating the challenges involved in establishing the CHPS regimen can intimidate local health officials. In addition to the operational complexity of the program, managers are concerned about sustainable funding and about the possibility that removing nurses from familiar locations and posting them in community health centers, often far from their families, will reduce their morale. These apprehensions have led to delays in implementing the program.

\section{Organizational diffusion}

Phillips and his colleagues are approaching the obstacles from a number of directions. "Social diffusion is the process of behavior or attitude change that happens among peers through social interaction. We are focusing on organizational diffusion, a process analogous to social diffusion, in which change can occur in institutions through the communication of ideas or the demonstration of new methods," says Phillips. The researchers have achieved particular success in facilitating connections among peers. They accompany teams of program officials on visits to field demonstration sites - such as one in Ghana's Nkwanta district - where staff members showcase their progress. Nkwanta is where the Navrongo model was first duplicated. The Nkwanta replication showed that CHPS could be launched in a non-research setting. This success helped to instill a feeling of "ownership" of the program among staff members. Studies of the diffusion of innovations within organizations consistently show that changes brought from the outside are more difficult to incorporate than transformations that arise from within institutions.

But not all staff members can attend field demonstrations. To increase information dissemination to everyone involved in the program, "we also have a journalist, Niagia Santuah, who produces a series of biweekly newsletters about community experiences in implementing the project, known as "What Works? What Fails?," says Phillips. "We combine this with a CD-ROM, distributed every
90 days by the Ghana Health Service to managers with budgetary authority at the national, regional, and district levels. The CD-ROM has maps of Ghana showing progress with the initiative, policy documents, and video clips." All of these communications tools help to build consensus among program staff that change is feasible, acceptable, and not as risky as it might seem at first glance.

"Health workers participating in CHPS tend to be strong proponents of the program, alluding to greater autonomy as well as community support for their work and the personal gratification that this generates," says Frank K. Nyonator, director of the Policy, Planning, Monitoring, and Evaluation division of the Ghana Health Service. Qualitative research suggests that the presence of a fully functioning pilot program in a district can greatly accelerate the district-wide implementation of CHPS. Once services are demonstrated on a small scale, widespread demand for community-based care builds. Positive experiences with the program and a sense of empowerment that comes from making a real difference in people's lives reduce nurses' concerns about relocation to another community.

"Small pilot programs should be fully scaled up in as many districts as possible," says J. Koku Awoonor-Williams of the Ghana Health Service's Nkwanta Health Development Center. "These pilot programs are becoming catalysts for change throughout Ghana and beyond."

SOURCES

Nyonator, Frank K., J. Koku Awoonor-Williams, James F. Phillips, Tanya C. Jones, and Robert A. Miller. 2005.

"The Ghana Community-based Health Planning and Services Initiative for scaling up service delivery innovation," Health Policy and Planning 20(1): 25-34. Awoonor-Williams, John Koku, Ellie S. Feinglass, Rachel Tobey, Maya N. Vaughan-Smith, Frank K. Nyonator, and Tanya C. Jones. 2004. "Bridging the gap between evidence-based innovation and national health-sector reform in Ghana," Studies in Family Planning 35(3): 161-177 (also issued as Policy Research Division Working Paper no. 191. New York: Population Council, http://www.popcouncil.org/pdfs/ wp/191.pdf).

OUTSIDE FUNDING

United States Agency for International Development 


\section{Can Livelihoods Training Alter Girls' Lives?}

A program providing reproductive health education and livelihoods skills training to adolescent girls in the slums of Allahabad, India, has shown that such interventions are acceptable to parents, feasible to implement, and exert some positive influence on the circumstances of girls. However, investigators found that narrowly focused, short-duration programs may fail to make a broad impact on girls' lives. The intervention also highlighted the difficulties inherent in fielding longitudinal surveys in urban slum areas.

\section{Girls' lives circumscribed}

While all adolescents in India face a rapidly changing economic environment, girls' life opportunities are very different from those of boys. Child marriage, defined as marriage before age 18, is common. Moreover, most young women have little say about the timing of marriage or the choice of spouse, and after marriage most young women have limited power within their new household. Girls are much less likely than boys to be engaged in economic activities. When young women do work, it is often in home-based jobs for which they may or may not be paid. Even in instances when young women are paid for their labor, they may not retain control over their income.

Given this situation, programs are needed that increase the ability of unmarried girls to have a say in their own lives and enhance the skills that expand life choices. "Livelihoods programs have the potential to increase young women's decisionmaking power by building social networks and developing income-generating and savings skills," says Council social scientist Mary P. Sebastian. As broadly conceived, the "livelihoods approach" to adolescent programs attempts to provide technical and life skills and seeks to transform the ways in which girls view themselves and the ways in which they are perceived by others in the community. Although a wide variety of livelihoods programs for adult women exist in India, few focus on adolescents. Of those that do, few employ rigorous scientific methods to evaluate the impact of the program.

\section{Testing feasibility and acceptability}

In 2001 the Population Council teamed with CARE-India to develop a pilot project for adolescent girls in the urban slums of Allahabad, Uttar Pradesh, the most populous of India's 28 states. Since 1995, CARE-India has been providing reproductive health services for adult women aged 20-49; and in 1999 reproductive health education for adolescent boys and girls aged 10-19 also became part of its activities.

\section{"Livelihoods programs}

have the potential to

increase young

women's decision-

\section{making power."}

The pilot project integrated livelihoods activities for adolescent girls aged 14-19 into CARE's reproductive health program for slum dwellers. Using a quasi-experimental study design, investigators divided the study area into an experimental and a control area. All adolescents taking part in the CARE program received reproductive health education from peer educators; only participants who lived in the experimental area, however, were provided with counseling on livelihoods, training in a range of vocational skills, assistance with opening savings accounts, and supportive follow-up counseling and assistance.

Group sessions on reproductive health were held in both areas weekly for 7-10 weeks. Following completion of the reproductive health component, participants in the experimental area attended vocational training classes.
Courses arranged by the project included tailoring, pot decoration, mehndi (painting of hands or feet), candle making, rug weaving, mending and embroidery, beekeeping, and food preservation. Over a span of ten months, 19 vocational courses were offered, each typically lasting 1-2 weeks, although some ran several months. Nearly 80 percent of participants completed two or more courses.

Baseline and endline surveys measured the impact of the project by comparing changes in various behaviors and attitudes among adolescents in the control and experimental areas before and after the intervention. The underlying premise of the intervention was that multiple benefits can accrue from synthesizing economic, social, and reproductive health activities. Specifically, the investigators wanted to see whether girls' physical mobility increased and whether they became more aware of safe places to gather with friends and mentors. Did they become more knowledgeable about reproductive health? Did their work aspirations blossom, and did they adopt more progressive ideas about gender roles? And finally, did they spend less time on domestic chores and more time visiting with friends, playing, or engaging in income-earning tasks?

\section{Findings from the baseline survey}

Several noteworthy findings from the baseline data revealed the restricted circumstances of girls' lives. Approximately half of the girls indicated that they had not traveled outside of Allahabad during the six months prior to the survey, compared to only about one-quarter of boys. Girls were much more likely than boys to report that they needed to seek permission to make visits outside of their homes. Both boys and girls reported that there are no places in the community where unmarried girls can safely congregate for any purpose.

The researchers also found girls' work lives to be substantially different from those of boys. Girls reported spending almost four times as many hours as boys on chores. The propor- 
tion of boys who reported that they have ever worked for pay was five times greater than the proportion of girls. However, despite the fact that girls were much less likely to work for pay, they were more inclined to save: 54 percent of girls and 26 percent of boys reported having some savings.

Reproductive health knowledge of certain topics was low. For example, very few adolescents in the survey knew about the fertile period of a woman's menstrual cycle, even though the large majority of girls and nearly 40 percent of boys reported that they knew about menstrual cycles in general. Although more than 90 percent of the respondents of both sexes reported knowing at least one contraceptive method, only about 33 percent of girls spontaneously reported knowing about condoms as compared with 82 percent of boys. Moreover, only about 37 percent of girls knew that condoms can protect against HIV/AIDS, as compared with 84 percent of boys.

\section{Evaluation of the project}

When conducting the endline survey, considerable effort was made to increase the number of adolescents interviewed, nearly doubling the survey's reach from 3,199 to 6,148 young people. Still, 1,312 adolescents who were interviewed at the baseline were not interviewed at the endline. Some of this loss is to be expected because of the relative mobility of slum populations and because adolescent girls who married likely moved to their conjugal households, outside of the study area.

Despite its brevity, the project had some significant effects on adolescent girls in Allahabad. Girls in the experimental areas were significantly more likely than the matched control respondents to know about safe locations for unmarried women to congregate, to be a member of a group, score higher on a social skills index, be informed about reproductive health, and spend time on leisure activities. All of these measures closely reflected the content of the project.

More than 80 percent of participants in the experimental area continued to use their vocational skills after the project ended. However, only 10 percent earned income from selling products that they made. One 19-yearold participant explained, "No one pays. I make things for free, without earning anything.... Women come and ask me to stitch clothes... [but] will not pay me." This finding suggests that to undertake new economic activities, girls may need more support than can be provided during a brief intervention.

Similarly, more than 50 percent of participants were able to open savings accounts in their name at the local post office, but there were significant obstacles to the continued operation of the accounts. The staff at the post office, who were male, frequently expressed their reluctance to assist adolescent girls. They often reprimanded girls for disturbing them, and sometimes even sent them away, asking them to return another day. As a result of these experiences, many girls were intimidated by

\section{"These findings show}

that parents must be

$$
\text { fully engaged in }
$$

discussions of the

importance of their

daughters' schooling,

liveliboods, and

$$
\text { delayed marriages." }
$$

the post office employees and were reluctant to spend money on repeated trips to the post office in order to manage their accounts.

The endline data also revealed no significant change in many crucial aspects of girls' lives. Levels of self-esteem remained unchanged, and girls in the experimental area were no more likely than girls in the control group to be able to visit relatives alone. Girls in the experimental area continued to hold rigid opinions about gender roles. Their aspirations for paid work in the future were no higher than those of girls in the control group. And they spent no more time with friends or on labor market work, nor less time on domestic chores, than did girls in the control group.
"In retrospect, the duration of the intervention was too short and its approach was not intensive enough to produce a sizable effect," said Population Council demographer Barbara Mensch, the investigation's lead researcher. "The girls were not involved in group meetings or vocational training for a long enough period of time to alter their attitudes or behavior significantly. Also, the intervention had only minimal contact with the girls' parents, who are largely in control of these girls' lives and futures. These findings show that parents must be fully engaged in discussions of the importance of their daughters' schooling, livelihoods, and delayed marriage."

Several lessons emerged from this pilot project. The intervention was both acceptable to parents in this traditional slum community and feasible to implement. Short-term projects such as this can increase awareness, social skills, knowledge of safe spaces, and group identification; however, they cannot be expected to alter the structure of opportunities available to adolescent girls. In order to reduce deeply entrenched gender disparities and enhance girls' ability to influence their own lives, it would be desirable for future projects to spend considerably more time with participants and with key community members, including parents, bank and postal workers, and others.
Sebastian, Mary P., Monica Grant, and Barbara Mensch. 2005. Integrating Adolescent Livelihood Activities within a Reproductive Health Programme for Urban Slum Dwellers in India. New Delhi: Population Council.

Mensch, Barbara S., Monica J. Grant, Mary P. Sebastian, Paul C. Hewett, and Dale Huntington. 2004. "The effect of a livelihoods intervention in an urban slum in India: Do vocational counseling and training alter the attitudes and behavior of adolescent girls?" Policy Research Division Working Paper No. 194. New York: Population Council.

\section{OUTSIDE FUNDING}

Department for International Development (DfID), UK; the Andrew W. Mellon Foundation; and the Office of Population and Reproductive Health, Bureau for Global Health, the United States Agency for International Development under the Population Council Program III cooperative agreement. 
continued from page 1

ly screening patients in both locations included a lack of training in domestic violence issues, a lack of time, and not having a solution to the problem. The majority of providers expressed interest in dealing with domestic violence and suggested that it would be important to receive training to be able to counsel women as part of antenatal care.

\section{Women's experiences}

Nearly one-quarter of the women interviewed in Karachi and one-third of the women interviewed in Kathmandu reported some form of physical abuse during the last pregnancy or earlier ones. Twenty-two percent of women in Karachi said they were slapped and 11 percent of them mentioned forced sexual intercourse. In Kathmandu, 32 percent of women reported being slapped and 22 percent mentioned forced sexual intercourse. "Obstetricians were shocked that the level of physical and sexual abuse during pregnancy was as high as women reported," says Fikree.

Only 10 percent of women in Karachi and Kathmandu who were injured by domestic violence sought help. Among those who sought assistance, most women were looking for someone to "mediate on their behalf" or sought help "to prevent wife beating." Women in both locations felt uncomfortable discussing domestic violence with health care providers and also felt that providers were uninterested and uncaring.

However, a little over half of the women interviewed in Karachi and nearly all the women interviewed in Kathmandu thought that an antenatal visit was an appropriate time for health care providers to routinely screen for domestic violence. In Karachi, women overwhelmingly identified doctors as the preferred health care provider to make this type of inquiry. In Kathmandu, women were about evenly split on whether a nurse or a doctor should make the inquiry.

\section{The cycle of violence}

"Previous research has suggested that exposure to violence in childhood —-both witness-

Attitudes and practices related to routine antenatal screening for domestic violence among obstetricians in Karachi and Kathmandu

Karachi

Percentage who approve of routine screening

47

Percentage who practice routine screening

3

77

Percentage moderately or very aware of strategies to help victims of domestic violence

Percentage moderately or very confident in making referrals

10

Percentage moderately or very aware of social workers or lawyers to assist victims of domestic violence

Source: Fikree et al. 2005.

ing and enduring violence - was a root cause of domestic violence in adulthood," says Fikree. In 1996, for example, Fikree and her colleagues interviewed 176 men in Karachi about their attitudes toward wife abuse and examined predictors for the risk of physical abuse. They found that 49 percent of men reported physically abusing their wives. Among these admitted abusers, 55 percent said they had been beaten as a child and 65 percent had witnessed their mother being beaten.

To follow up on these findings, the researchers asked the women in Karachi and Kathmandu about the effects of domestic violence on their children. In Karachi, 49 percent of women said that their children had witnessed them being abused. Half of those children were physically abused as well. In Kathmandu, 44 percent of women said that their children had witnessed them being abused. Forty-eight percent of those children were also physically abused. "How many of these abused children will go on to become abusers?" asks Fikree.

\section{Proposed intervention strategies}

Raising awareness about the enormity of physical abuse during pregnancy might motivate obstetricians to institute routine domestic violence screening. The investigators believe that interventions by the medical community, such as routine screening by obstetricians during antenatal visits, are necessary and will be welcomed by women. Appropriate counseling and referral systems must be instituted prior to implementing routine screening programs. Given the findings about the level of child abuse and the evidence that abused children often go on to become abusers, program managers should develop separate interventions to stop child abuse. "Detecting and preventing child abuse will be a key step in breaking the cycle of violence," says Fikree.

\section{SOURCES}

Fikree, Fariyal F., Sadiqua N. Jafarey, Razia Korejo, Anjum Afshan, and Jill M. Durocher. "Intimate partner violence before and during pregnancy: Experiences of postpartum women in Karachi, Pakistan," Journal of Pakistan Medical Association, forthcoming

Deuba, Arzu Rana and Pinky Singh Rana. 2005. A Study on Linkages Between Domestic Violence and Pregnancy. Kathmandu, Nepal: SAMANTAInstitute for Social and Gender Equality.

Fikree, Fariyal F., Junaid A. Razzak, and Jill Durocher. 2005. "Attitudes of Pakistani men to domestic violence: A study from Karachi, Pakistan," International Journal on Men's Health and Gender 2(1): 49-58.

Fikree, Fariyal F., Sadiqua N. Jafarey, Razia Korejo, Ambareen Khan, and Jill M. Durocher. 2004.

"Pakistani obstetricians' recognition of and attitude towards domestic violence screening," International Journal of Gynecology and Obstetrics 87(1): 59-65.

Fikree, Fariyal F., Sadiqua N. Jafarey, Razia Korejo, Ambareen Khan, Anjum Afshan, and Jill M. Durocher. 2003. "Obstetricians' and women's perspectives: A case study of domestic violence from Pakistan." New York: Population Council.

\section{OUTSIDE FUNDING}

Aga Khan University, the William and Flora Hewlett Foundation, and the John D. and Catherine T. MacArthur Foundation 


\section{RECENT PUBLICATIONS}

\section{Biomedicine}

Ge, Renshan S., Qiang Dong, Enmei Niu, Chantal M. Sottas, Dianne O. Hardy, James F. Catterall, Syed A. Latif, David J. Morris, and Matthew P. Hardy. "11 $\beta$-hydroxysteroid dehydrogenase 2 in rat Leydig cells: Its role in blunting glucocorticoid action at physiological levels of substrate," Endocrinology 146(6): 2657-2664.

Ge, Renshan S., Qiang Dong, Chantal M. Sottas, Haolin Chen, Barry R. Zirkin, and Matthew P. Hardy. "Gene expression in rat Leydig cells during development from the progenitor to adult stage: A cluster analysis," Biology of Reproduction 72(6): 1405-1415.

Lui, Wing Yee, Yan H. Cheng, Dolores D. Mruk, Chin H. Cheng, Meng Y. Mo, Will M. Lee, and C. Yan Cheng. " $\alpha_{2}$-macroglogulin expression in the liver in response to inflammation is mediated by the testis," Journal of Endocrinology 185(3): 497-505.

Peretti, Silvia, James Blanchard, Rudolf Bohn, Gavin Morrow, Jeffrey D. Lifson, Agegnehu Gettie, and Melissa Pope. "Immunomodulatory effects of HSV-2 infection on immature macaque dendritic cells modify innate and adaptive responses," Blood 106(4): 1305-1313.

Sitruk-Ware, Régine. "Delivery options for contraceptives," Drug Discovery Today 10(14): 977-985.

_. "Vaginal delivery of contraceptives," Expert Opinion on Drug Delivery 2(4): 729-736.

Siu, Michelle K.Y., Ching-hang Wong, Will M. Lee, and C. Yan Cheng. "Sertoli-germ cell anchoring junction dynamics in the testis are regulated by an interplay of lipid and protein kinases," Journal of Biological Chemistry 280(26): 25029-25047.

\section{Zhang, Jiayi, Dolores D. Mruk, and C. Yan Cheng.}

“Myotubularin phosphoinositide phosphatases, protein phosphatases, and kinases: Their roles in junction dynamics and spermatogenesis," Journal of Cellular Physiology 204(2): 470-483.

\section{Gender and Family Dynamics}

Chege, Jane. "Interventions linking gender relations and violence with reproductive health and HIV: Rationale, effectiveness and gaps," Agenda: Special Focus on Gender, Culture and Rights (special issue): 114-123.

Hallman, Kelly, Agnes Quisumbing, Marie Ruel, and Bénédicte de la Brière. "Mothers' work and child care: Findings from the urban slums of Guatemala," Economic Development and Cultural Change 53(4): 855-886.

Haque, Faizal, John Townsend, and M.E. Khan. "Marital sexual violence is 'a terrifying experience,'" Network 23(4): 12.

Pradeep, Panda and Bina Agarwal. "Marital violence, human development and women's property status in India," World Development 33(5): 823-850.

\section{HIV/AIDS}

Baek, Carolyn and Naomi Rutenberg. "Addressing the family planning needs of HIV-positive PMTCT clients: Baseline find ings from an operations research study," Horizons Research Update. Washington, DC: Population Council.

Homan, Rick and Catherine Searle. "Exploring the role of family caregivers and home-based care programs in meeting the needs of people living with HIV/AIDS in South Africa,"

Horizons Research Update. Washington, DC: Population Council.

. "Programmatic implications of a cost study of homebased care programs in South Africa," Horizons Research Update. Washington, DC: Population Council.

\section{Infants and Children}

Hossain, Mian Bazle, James F. Phillips, and Thomas K. LeGrand. "The impact of childhood mortality on fertility in six rural thana of Bangladesh," Policy Research Division Working Paper no. 198. New York: Population Council.

"Psychosocial support for children," Horizons Report, June 2005. Washington, DC: Population Council.

\section{Quality of Care}

Foreit, Karen G. Fleischman and James R. Foreit. "Enquêtes d'acceptation de paiment destinées à déterminer les prix des produits et services dan le domaine de la santé de la reproduction : manuel de l'utilisateur" [Willingness-to-pay surveys for setting prices for reproductive health products and services: A user's manual], FRONTIERS Report. Washington, DC: Population Council.

\section{León, Federico R., Carlos Brambila, Marisela de la Cruz, Julio} García Colindres, Carlos Morales, and Benedicto Vásquez. "Providers' compliance with the balanced counseling strategy in Guatemala," Studies in Family Planning 36(2): 117-126.

Rob, Ubaidur, Nancy J. Piet Pelon, and Marium ul Mutahara. "When family planning services fail: Experience from Bangladesh," International Quarterly of Community Health Education 23(2): 151-167.

Rob, Ubaidur, Md. Noorunnabi Talukder, Md. Mahabub-ulAnwar, Laila Rahman, and Marium ul Mutahara. "Health sector reform in developing countries: Trends and lessons learned." Dhaka: Population Council and Canadian International Development Agency.

\section{Reproductive Health}

Adamchak, Susan. "Lessons learned from the global agenda of the Frontiers in Reproductive Health Program," FRONTIERS report. Washington, DC: Population Council.

Bratt, John, Nahla Abdel-Tawab, Magdi Ibrahim, and Mohammed Edress. "Willingness-to-pay for services provided by the Clinical Services Improvement Project (CSI) in Egypt," FRONTIERS Final Report. Cairo: Population Council.

"Burkina Faso: Community education program scaled-up in Burkina Faso," FRONTIERS OR Summary no. 55. Washington, DC: Population Council.

“A client-centered approach to reproductive health: A trainer' manual." Islamabad: Population Council.

Gonzáles, Fernando and Patricia Riveros. "Technical assistance and training for the CIES Operations Research Program, Bolivia," FRONTIERS report. Washington, DC: Population Council.

"India: Broad representation supports credibility of village committees," FRONTIERS OR Summary no. 52. Washington, DC: Population Council.

“India: Enhancing girls' life skills requires long-term commitment," FRONTIERS OR Summary no. 53. Washington, DC: Population Council.

Khan, M.E., Sandhya Barge, Hemlata Sadhwani, and Giteshwari Kale. "Knowledge, attitude, and experience of marriage and sexuality among newly married women in Gujarat, India: An exploratory study," International Quarterly of Community Health Education 23(3): 215-251.

Khan, M.E., Sharif Mohammed Ismail Hossain, and Md Nizamuddin Bhuiyan. "Building national capacity to deliver emergency contraceptive services in Bangladesh," FRONTIERS Research Update no. 3. Dhaka: Population Council.

Mekbib, Tekle-Ab, Annabel Erulkar, and Fekerte Belete. "Who are the targets of youth programs: Results of a capacity building exercise in Ethiopia," Ethiopian Journal of Health Development 19(1): 60-62.

Mugisha, Frank, Harriet Birungi, and lan Askew. "Are reproductive health NGOs in Uganda able to engage in the health SWAp?" International Journal of Health Planning and Management 20(3): 227-238.

Mullick, Saiqa, Busi Kunene, and Monica Wanjiru. “Involving men in maternity care: Health delivery issues," Agenda: Special Focus on Gender, Culture and Rights (special issue): 124-135.

“Nepal: Support communication to enhance young mothers reproductive health," FRONTIERS OR Summary no. 51.

Washington, DC: Population Council.

Sebastian, Mary P., Monica Grant, and Barbara Mensch. "Integrating adolescent livelihood activities within a reproduc tive health programme for urban slum dwellers in India." New Delhi: Population Council.

"Senegal: Community education program increases dialogue on FGC," FRONTIERS OR Summary no. 54. Washington, DC: Population Council.
Sloan, Nancy L., Nguyen Thi Nhu Ngoc, Do Trong Hieu, Charlotte Quimby, Beverly Winikoff, and Goli Fassihian. “Effectiveness of lifesaving skills training and improving institutional emergency obstetric care readiness in Lam Dong, Vietnam," Journal of Midwifery \& Women's Health 50(4): 315-323.

\section{Social Science}

Kaneda, Toshiko, Zachary Zimmer, and Zhe Tang.

"Socioeconomic status differentials in life and active life expectancy among older adults in Beijing," Disability and Rehabilitation 27(5): 241-251.

Mensch, Barbara S., Susheela Singh, and John B. Casterline. "Trends in the timing of first marriage among men and women in the developing world," Policy Research Division Working Paperno. 202. New York: Population Council.

Montgomery, Mark R. Review of Robert Neuwirth, Shadow Cities: A Billion Squatters, a New Urban World, Population and Development Review 31(2): 373-376.

Montgomery, Mark R. and Alex C. Ezeh. “Developing-country urban health: Insights from demographic theory and practice," in Sandro Galea and David Vlahov (eds.), Handbook of Urban Health: Populations, Methods, and Practice. New York: Springer, pp. 317-360.

. "Urban health in developing countries: An overview," in Sandro Galea and David Vlahov (eds.), Handbook of Urban Health: Populations, Methods, and Practice. New York: Springer, pp. 201-222.

Montgomery, Mark and Paul Hewett. "Poverty and children's schooling: A structural equations approach using MICS data," in E. Minujin, E. Delamonica, and M. Komarecki (eds.), Human Rights and Social Policies for Children and Women: The Multiple Indicator Cluster Survey (MICS) in Practice. New York: New School University with the support of UNICEF.

. "Urban poverty and health in developing countries: Household and neighborhood effects," Demography 42(3): 397-425.

Osei, Ivy, Harriet Birungi, Gifty Addico, lan Askew, and John Gyapong. "What happened to the IUD in Ghana?" African Journal of Reproductive Health 9(1): 85-100.

Pence, Brian Wells, Philomena Nyarko, James F. Phillips, and Cornelius Debpuur. "The effect of community nurses and health volunteers on child mortality: The Navrongo Community Health and Family Planning Project," Policy Research Division Working Paperno. 200. New York: Population Council.

Phillips, James F., Tanya C. Jones, Frank K. Nyonator, and Shruti Ravikumar. "Evidence-based scaling up of health and family planning service innovations in Bangladesh and Ghana," in Ruth Simmons, Peter Fajans, and Laura Ghiron (eds.), Scaling Up Health Service Delivery: From Pilot Innovations to Policies and Programmes. Geneva: World Health Organization.

Rob, Ubaidur, Mohammed Kabir, and Marium ul Mutahara. "Urbanization in Bangladesh," in Gayl D. Ness and Prem P. Talwar (eds.), Asian Urbanization in the New Millennium. Singapore: Asian Urban Information Center of Kobe and Marshall Cavendish Academic, pp. 25-54.

Zimmer, Zachary. "Active life expectancy and functional limitations among older Cambodians: Results from a 2004 survey," Policy Research Division Working Paper no. 201. New York: Population Council.

Zimmer, Zachary, Linda G. Martin, Mary Beth Ofstedal, and YiLi Chuang. "Education of adult children and mortality of their elderly parents in Taiwan," Policy Research Division Working Paper no. 199. New York: Population Council.

\section{Transitions to Adulthood}

"Building assets for safe, productive lives: A report on a workshop on adolescent girls' livelihoods, 7-8 April 2004." New York: Population Council.

Promoting Healthy, Safe, and Productive Transitions to Adulthood Brief, a series of ten briefs and an overview. New York: Population Council.

Publications are by Population Council staff members, consultants, or staff from partner organizations. Year of publication is 2005 unless otherwise noted. Names in boldface are staff members or those from partner organizations. 


\section{(P) Population Council}

One Dag Hammarskjold Plaza, New York, NY 10017

Population Briefs is a research newsletter of the Population Council. The Council is an international, nonprofit, nongovernmental organization that

seeks to improve the well-being and reproductive health of current and future generations around the world and to help achieve a humane, equitable, and sustainable balance between people and resources. The Council conducts biomedical, social science, and public health research and helps build research capacities in developing countries. Established in 1952, the Council is governed by an international board of trustees. Its New York headquarters supports a global network of regional and country offices.

Writer/Editor: Gina Duclayan

Editorial Board: Cynthia B. Lloyd, Melissa May, Irving Sivin, C. Johannes van Dam Production Manager: Y. Christina Tse Production Artist: Sura Rosenthal Copyeditor: Robert Heidel Editorial Assistant: Jared Stamm Circulation: Debra Warn

Population Briefs is distributed without charge. Information in this newsletter may be reproduced without permission, provided it is distributed without charge and the source is acknowledged.

To receive e-mail when a new issue of Population Briefs is posted to the Population Council Web site, register at www.popcouncil.org/signup ISSN 1084-6786

(C)2005 The Population Council, Inc.

\section{IN THIS ISSUE}

\section{VIOLENCE AGAINST WOMEN}

Among admitted abusers, 55 percent said they had been beaten as a child and 65 percent had witnessed their mother being beaten.

See page 1

\section{EXPERIMENTAL PROGRAMS}

"In Ghana, we are taking mechanisms that work for individual behavior change and adapting them for the purpose of policy and program change within institutions."

See page 3

\section{BIOMEDICINE}

Biomedical researchers have found that exposure to low levels of phthalates can alter levels of sex hormones, increase the proliferation of cells in the testes, and significantly accelerate the onset of puberty. 